\title{
Article
}

Subscriber access provided by University of Florida | Smathers Libraries

\section{Enhanced stress response in 5-HTR overexpressing mice: altered HPA function and hippocampal long-term potentiation}

Fuencisla Pilar-Cuellar, Rebeca Vidal Casado, Alvaro Diaz, Emilio Garro-

Martinez, Raquel Linge, Elena Castro, Robert Haberzettl, Heidrun Fink, Bettina

Bert, Jan Brosda, Beatriz Romero, Benedicto Crespo Facorro, and Angel Pazos

ACS Chem. Neurosci., Just Accepted Manuscript • DOI: 10.1021/acschemneuro.7b00156 • Publication Date (Web): 04 Aug 2017

Downloaded from http://pubs.acs.org on August 5, 2017

\section{Just Accepted}

"Just Accepted" manuscripts have been peer-reviewed and accepted for publication. They are posted online prior to technical editing, formatting for publication and author proofing. The American Chemical Society provides "Just Accepted" as a free service to the research community to expedite the dissemination of scientific material as soon as possible after acceptance. "Just Accepted" manuscripts appear in full in PDF format accompanied by an HTML abstract. "Just Accepted" manuscripts have been fully peer reviewed, but should not be considered the official version of record. They are accessible to all readers and citable by the Digital Object Identifier (DOI®). "Just Accepted" is an optional service offered to authors. Therefore, the "Just Accepted" Web site may not include all articles that will be published in the journal. After a manuscript is technically edited and formatted, it will be removed from the "Just Accepted" Web site and published as an ASAP article. Note that technical editing may introduce minor changes to the manuscript text and/or graphics which could affect content, and all legal disclaimers and ethical guidelines that apply to the journal pertain. ACS cannot be held responsible for errors or consequences arising from the use of information contained in these "Just Accepted" manuscripts. 
Instituto de Biomedicina y Biotecnología (IBBTEC); Facultad de Medicina, Universidad de Cantabria-CSIC-SODERCAN; Departamento de Fisiología y Farmacología, Universidad de Cantabria

\section{SCHOLARONE ${ }^{\text {M }}$}

Manuscripts 
1 TITLE PAGE

2 TITLE: Enhanced stress response in 5- $\mathrm{HT}_{1 \mathrm{~A}} \mathrm{R}$ overexpressing mice: altered HPA

3 function and hippocampal long-term potentiation

4

5 AUTHORS:

6 Fuencisla Pilar-Cuéllar ${ }^{1,2,3, *}$, Rebeca Vidal ${ }^{4,5}$, Álvaro Díaz ${ }^{1,2,3}$, Emilio Garro-Martínez ${ }^{1,2,3}$, 7 Raquel Linge ${ }^{1,2,3}$, Elena Castro ${ }^{1,2,3}$, Robert Haberzettl ${ }^{6}$, Heidrun Fink ${ }^{6}$, Bettina Bert ${ }^{6}$, 8 Jan Brosda ${ }^{6}$, Beatriz Romero ${ }^{1,2,3}$, Benedicto Crespo-Facorro ${ }^{1,7}$, Ángel Pazos ${ }^{1,2,3}$

10 AFFILIATIONS:

$11{ }^{1}$ CIBERSAM, Instituto de Salud Carlos III, Santander, Spain

122 Instituto de Biomedicina y Biotecnología (IBBTEC); Facultad de Medicina, 13 Universidad de Cantabria-CSIC-SODERCAN, Santander, Spain

$14{ }^{3}$ Departamento de Fisiología y Farmacología, Universidad de Cantabria, Santander, 15 Spain

$16{ }^{4}$ Departamento de Farmacología, Facultad de Medicina, Universidad Complutense, 17 Instituto de Investigación Sanitaria del Hospital Clínico San Carlos (IdISSC).

$18{ }^{5}$ Red de Trastornos Adictivos del Instituto de Salud Carlos III, Madrid, Spain.

$19{ }^{6}$ Institut für Pharmakologie und Toxikologie, Fachbereich Veterinärmedizin, Freie 20 Universität Berlin, Berlin, Germany

$21{ }^{7}$ Hospital Universitario Marqués de Valdecilla, University of Cantabria-IDIVAL, School 22 of Medicine, Department of Psychiatry, Santander, Spain

23

24 * CORRESPONDING AUTHOR:

25 ORCID: orcid.org/0000-0003-1229-001X

26 E-mail: pilarmf@unican.es 
1 Instituto de Biomedicina y Biotecnología de Cantabria, IBBTEC (Universidad de 2 Cantabria, CSIC, SODERCAN)

3 Avda. Albert Einstein, 22,

$4 \quad 39011$ Santander, Spain.

5

6

7 SHORT TITLE: Blunted stress response in 5- $\mathrm{HT}_{1 \mathrm{~A}} \mathrm{R}$ overexpressing mice

8

9

10

11 
Fuencisla Pilar-Cuéllar et al.

1 ABSTRACT

2 Postsynaptic 5- $\mathrm{HT}_{1 \mathrm{~A}}$ receptors $\left(5-\mathrm{HT}_{1 \mathrm{~A}} \mathrm{R}\right)$ play an important role in anxiety and stress,

3 although their contribution is still controversial. Previous studies report that mice

4 overexpressing postsynaptic $5-\mathrm{HT}_{1 \mathrm{~A}} \mathrm{Rs}$ show no changes in basal anxiety, though the

5 influence of stress conditions has not been addressed yet. In this study, we used this

6 animal model to evaluate the role of $5-\mathrm{HT}_{1 \mathrm{~A}} \mathrm{Rs}$ in anxiety response after pre-exposure

7 to an acute stressor. Under basal conditions, $5-\mathrm{HT}_{1 \mathrm{~A}} \mathrm{R}$ overexpressing animals

8 presented high corticosterone levels and a lower mineralocorticoid/glucocorticoid

9 receptor ratio. After pre-exposure to a single stressor, they showed a high anxiety-like

10 response, associated to a blunted increase in corticosterone levels and higher c-Fos

11 activation in the prefrontal cortex. Moreover, these mice also presented a lack of

12 downregulation of hippocampal long-term potentiation after stress exposure. Therefore,

13 higher postsynaptic 5- $\mathrm{HT}_{1 \mathrm{~A}} \mathrm{R}$ activation might predispose to a high anxious phenotype

14 and an impaired stress coping behavior.

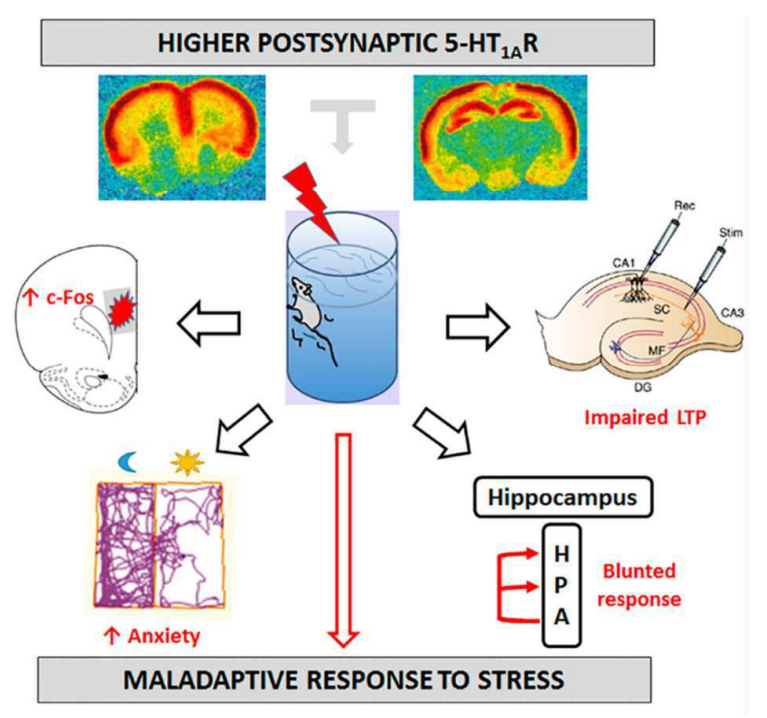

17

18 KEYWORDS: postsynaptic 5-HT $\mathrm{HA}_{1 \mathrm{~A}}$ receptor; anxiety; behavior; HPA axis; c-Fos; long19 term potentiation. 
2 The serotonergic system is one of the key neurotransmitter systems in the body, 3 implicated in the neurobiology of anxiety, depression and impulsive behavior, as well 4 as in the control of other physiological functions as food intake, temperature control, 5 sexual behavior, and the modulation of learning and memory (1). The $5-\mathrm{HT}_{1 \mathrm{~A}}$ receptor $6\left(5-H T_{1 A} R\right)$ subtype is one of the most relevant, with a dual localization as an 7 autoreceptor in the soma of the serotonergic neurons located in the raphe nuclei, and 8 as a heteroreceptor in postsynaptic areas as hippocampus and cortex (2). This 9 receptor subtype is implicated in psychiatric pathologies as bipolar disorder (3), panic disorder (4), anxiety (5), and depression (6). The involvement of the $5-H T_{1 A} R$ in dysfunctional forms of anxiety has been studied in a wide range of preclinical research and clinical trials, including drug treatment studies, genetic research, and neuroimaging data (7). Studies in transgenic mice also demonstrate the important role of forebrain 5$\mathrm{HT}_{1 \mathrm{~A}}$ receptors regulating both anxious (8) and depressive (6) behaviors. Increased circulating corticosterone levels induced by stress, have been associated to a downregulation of postsynaptic $5-\mathrm{HT}_{1 \mathrm{~A}}$ receptor expression and functionality in hippocampus $(9,10)$. Moreover, a dysregulated HPA function is associated with anxious/depressive-like behavior $(11,12)$. Corticosterone binds to two different receptors: mineralocorticoid receptors (MRs), present in limbic areas, and glucocorticoid receptors (GRs), more ubiquitous (13). The high-affinity MRs are saturated under basal corticosterone levels, whereas the low-affinity GRs are recruited by stress-induced high corticosteroid levels, playing a role in the negative feedback inhibition of the HPA axis (13). HPA hyperactivity leads to a downregulation of GRs and, consequently, to an impaired negative feedback inhibition (14). The subsequent glucocorticoid hypersecretion together with high serotonin release in postsynaptic areas involved in the response to stress results in the $5-\mathrm{HT}_{1 \mathrm{~A}} \mathrm{R}$ downregulation in areas as the hippocampus, a neurochemical finding associated to stress-related disorders (6). In humans, a blunted cortisol variation is associated to greater scores in depressive symptoms (15).

High corticosterone levels impair long-term potentiation (LTP) in the dorsal CA1 region 31 of the hippocampus (16), particularly, the LTP mediated by N-methyl-D-aspartate 32 (NMDA) receptors (NMDA receptor-dependent LTP) (17). Elevated levels of 33 corticosteroid hormones occupying both $\operatorname{GRs}$ and MRs $(13,18)$ impair the acquisition 34 of hippocampal-dependent memories. These MRs and GRs produce opposite effects 
1 on LTP in CA1, either facilitating or suppressing the LTP activation, respectively,

2 leading to the induction of long-term depression (18). In fact, MR activity seems to

3 maintain the excitability and stability of networks, while GR activation is involved in the

4 suppression and normalization of network activity (13). Under low corticosterone levels,

5 there is a predominant activation of MR that results in small $\mathrm{Ca}^{2+}$ currents that preserve

6 the LTP (19). The exposure to high corticosterone levels promotes an additional GR

7 activation, increasing the intracellular $\mathrm{Ca}^{2+}$ concentrations (20), and blocking the NMDA

8 receptors, leading to an impaired hippocampal LTP (20).

9 Recently, a transgenic mouse line with a permanent $5-\mathrm{HT}_{1 \mathrm{~A}} \mathrm{R}$ overexpression (OE 10 mice) was generated $(21,22,23)$. These $\mathrm{OE}$ mice overexpress $5-\mathrm{H} \mathrm{T}_{1 \mathrm{~A}} \mathrm{R}$ in cortex, 11 hippocampus and other limbic areas, whereas their expression was not altered in the 12 raphe nucleus. Previous studies using ethological- and conflict-based behavioral tests, 13 demonstrated that the permanent postsynaptic $5-\mathrm{HT}_{1 \mathrm{~A}} \mathrm{R}$ overexpression in mice does 14 not result in significant changes in basal anxiety-related responses (22). However, we 15 postulate that the high post/presynaptic $5-\mathrm{HT}_{1 \mathrm{~A}}$ receptor ratio must be influencing their 16 vulnerability to stress. Therefore, we have evaluated the behavioral response of mice 17 overexpressing postsynaptic $5-\mathrm{HT}_{1 \mathrm{~A}} \mathrm{Rs}$ in anxiety tests following a forced swimming 18 session used as an acute stressor. In addition, we measured the associated serum 19 corticosterone and corticosteroid receptors levels to analyze the HPA axis functionality. 20 c-Fos activation in the prefrontal cortex and hippocampal LTP were also evaluated in 21 these animals under basal conditions, and following acute stress.

\section{RESULTS AND DISCUSSION}

In the present study, we demonstrate the enhanced anxiety response of mice overexpressing $5-\mathrm{HT}_{1 \mathrm{~A}} \mathrm{R}$ in postsynaptic areas $\left(5-\mathrm{HT} \mathrm{T}_{1 \mathrm{~A}} \mathrm{OE}\right.$ mice) when they are preexposed to a single forced swimming session used as a stressor factor, associated with an altered HPA axis response, prefrontal cortex activation and a sustained 28 hippocampal LTP. 
1 In this study, we used a transgenic mouse line that overexpresses $5-\mathrm{HT}_{1 \mathrm{~A}}$ receptors in 2 postsynaptic areas (i.e. hippocampus and cerebral cortex) $(21,23)$. To evaluate the 5$3 \mathrm{HT}_{1 \mathrm{~A}}$ receptor functionality, we performed a functional autoradiography using the 4 selective $5-\mathrm{HT}_{1 \mathrm{~A}}$ receptor agonist $8-\mathrm{OH}-\mathrm{DPAT}$. The agonist-mediated $\left[{ }^{35} \mathrm{~S}\right] \mathrm{GTP} \gamma \mathrm{S}$ 5 stimulation was significantly higher in postsynaptic areas as the medial prefrontal 6 cortex $(p<0.01)$, the CA1 area of the hippocampus $(p<0.05)$ and the CA3 area of the 7 dorsal hippocampus $(p<0.05)$ in $5-\mathrm{HT}_{1 \mathrm{~A}} \mathrm{R}$ OE mice. No significant differences were 8 observed in $5-\mathrm{HT}_{1 \mathrm{~A}} \mathrm{R}$ functionality in the dentate gyrus, paraventricular nucleus of the 9 hypothalamus, and the dorsal raphe nucleus (Figure 1). Basal $\left[{ }^{35} \mathrm{~S}\right] \mathrm{GTP} \gamma \mathrm{S}$ binding 10 values were similar in both WT and OE animals in the different areas studied (Table 11 S1, Supporting Information).

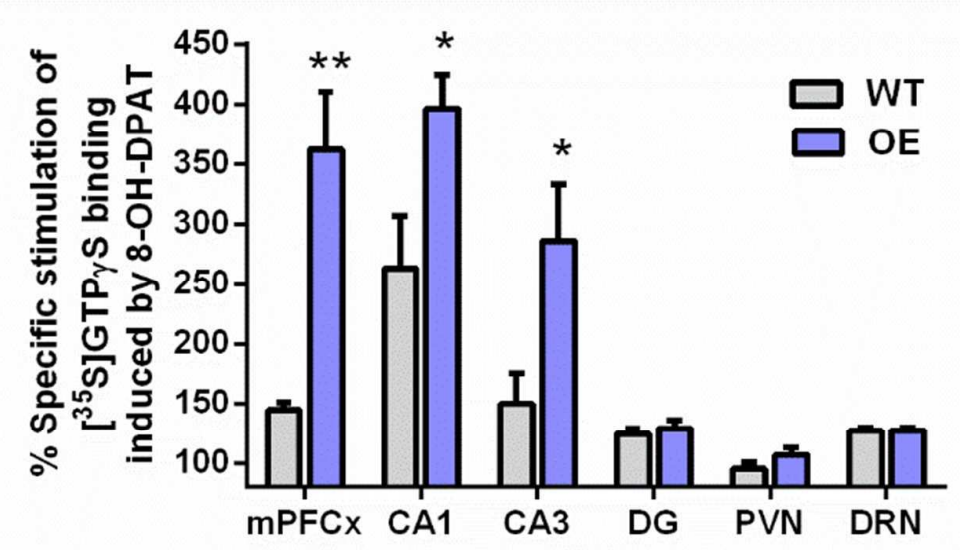

Figure 1. Autoradiographic 8-OH-DPAT-stimulated $\left[{ }^{35} \mathrm{~S}\right] \mathrm{GTP} \gamma \mathrm{S}$ binding in WT and OE mice. Data are expressed as the mean \pm SEM. Student $t$-test analysis comparing OE and WT values in each brain area; ${ }^{*} p<0.05$ and ${ }^{* *} p<0.01$. mPFCx (medial prefrontal cortex), CA1 (CA1 field of the hippocampus), CA3 (CA3 field of the hippocampus), DG (dentate gyrus of the hippocampus), PVN (paraventricular nucleus of the hypothalamus) and DRN (dorsal raphe nucleus). $n=5-6$ animals per group.

21 These data confirm the increased functionality of postsynaptic 5-HT ${ }_{1 \mathrm{~A}} R \mathrm{~s}$ 22 overexpressed in these transgenic mice compared to their WT counterparts, with no 23 differences in presynaptic $5-\mathrm{HT}_{1 \mathrm{~A}} \mathrm{Rs}$ functionality (dorsal raphe nucleus). This higher 
1 receptor functionality is in good agreement with the elevated receptor density observed

2 in studies using $\left[{ }^{3} \mathrm{H}\right] 8-\mathrm{OH}-\mathrm{DPAT}$ (23). Although postsynaptic $5-\mathrm{HT}_{1 \mathrm{~A}} \mathrm{R}$ OE mice do not

3 present changes in 5-HT levels in projection areas compared to WT animals (22), the

4 higher density/functionality of postsynaptic $5-\mathrm{HT}_{1 \mathrm{~A}}$ receptors may lead to a region-

5 dependent serotonin imbalance that could determine the behavioral outcome

6 depending on which brain areas are engaged in different environmental challenges.

\section{Anxiety-like responses are enhanced after acute stress in 5-HT ${ }_{1 A}$ OE mice}

9 Taken into account the importance of the $5-\mathrm{HT}_{1 \mathrm{~A}} \mathrm{Rs}$ in the vulnerability to stress (24, 10 25), we assessed the anxiety-like response of the 5- $\mathrm{HT}_{1 \mathrm{~A}}$ OE mice after the pre11 exposure to an acute stressor (5 minutes forced swimming session). In the light/dark 12 box test, non-stressed OE animals spent more time in the lit compartment than their 13 WT counterparts $(p<0.05)$. The exposure to an acute stressor immediately before behavioral testing, induced no changes in WT animals, but elicited an anxious response in $\mathrm{OE}$ animals, evidenced by a lower ratio light/dark time compared to the naïve OE mice $(p<0.001)$ (Figure $2 A)$. A two-way ANOVA analysis of the ratio light/dark time showed a significant effect of the stress $[F(1,31)=20.51, p<0.001]$, and the interaction genotype $x$ stress $[F(1,31)=18.58, p<0.001]$. Bonferroni posthoc analysis showed differences between WT and OE mice $(p<0.05)$ and OE naïve and stressed animals $(p<0.001)$, and between WT stress and OE stress mice $(p<0.05)$. No changes in locomotion were observed in OE mice under basal and stress conditions (Figure S1, Supporting Information).

In the novelty suppressed feeding (NSF) non-stressed WT and 5- $\mathrm{HT}_{1 \mathrm{~A}} \mathrm{R}$ OE animals presented a similar delay to approach and eat the food pellet, whereas the preexposure to stress produced a higher increase in the latency to feed in OE animals $(p<0.001)$ (Figure 2B). A two-way ANOVA analysis of the latency to feed showed a significant effect of the genotype $[F(1,31)=7.57, p<0.01]$, the stress $[F(1,31)=21.99$, $p<0.001]$, and the interaction genotype $x$ stress $[F(1,31)=6.73, p<0.05]$. The $5-\mathrm{HT}_{1 \mathrm{~A}} \mathrm{OE}$ group presented lower food consumption in the post-test compared to the WT animals

30 (Figure S2, Supporting Information), though no differences in their daily homecage 31 consumption were detected (data not shown). 

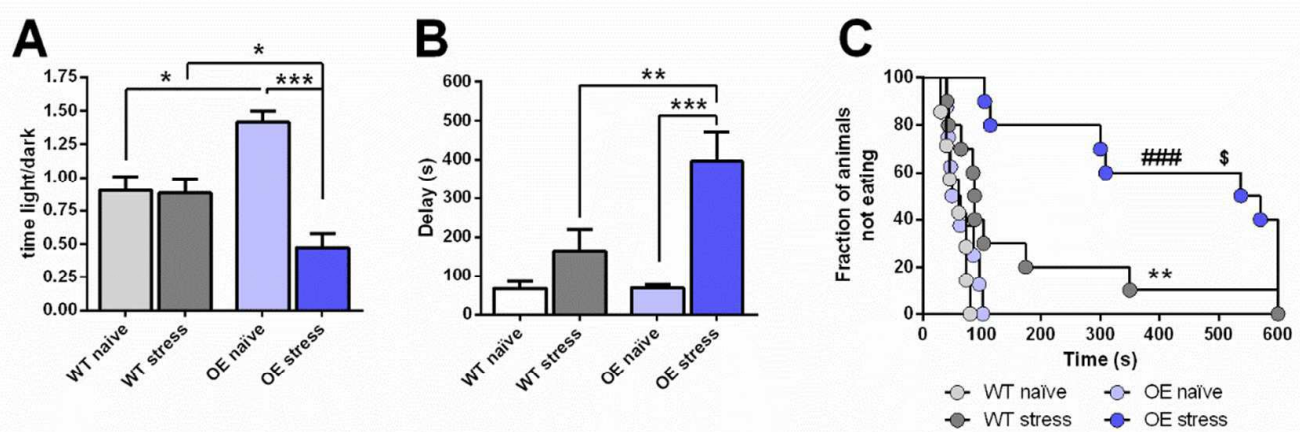

1

2 Figure 2. Anxiety- and depression-related behaviors in WT and 5-HT ${ }_{1 A} R$ OE mice. (A)

3 Ratio of time spent in the lit compartment $v s$ the dark one in the light/dark box test. (B)

4 Latency to feeding in the novelty suppressed feeding test in OE mice and WT

5 counterparts under basal and acute stress conditions. Two-way ANOVA followed by

6 Bonferroni post-hoc test; ${ }^{*} p<0.05,{ }^{* *} p<0.01,{ }^{* * *} p<0.001$. (C) Survival analysis and

7 statistical differences between the latencies determined by the Kaplan-Meier product-

8 limit method; ${ }^{* *} p<0.01$ WT stress vs WT naïve, \#\#\#p<0.001 OE stress vs OE naïve,

$9 \$ p<0.05$ OE stress vs WT stress. Note the higher anxiogenic response of OE mice when pre-exposed to stress. Data expressed as the mean \pm SEM. $n=6-10$ animals per group.

Our results demonstrate that mice overexpressing postsynaptic $5-\mathrm{HT}_{1 \mathrm{~A}} \mathrm{Rs}$ exhibit different anxiety-like responses in non-stressed animals depending on the behavioral test. Both postsynaptic 5- $\mathrm{HT}_{1 \mathrm{~A}} \mathrm{R}$ OE mice and their WT counterparts showed a similar anxiety-like response under non-stressing conditions in the novelty suppressed feeding test, in line with previous findings in the elevated plus maze (22), though postsynaptic $5-\mathrm{HT}_{1 \mathrm{~A}} \mathrm{R}$ OE mice displayed less anxiety-like behavior in the light/dark paradigm. It is noteworthy that postsynaptic $5-\mathrm{HT}_{1 \mathrm{~A}} \mathrm{R}$ overexpressing mice used in this work are constitutive, which can result in compensatory changes associated with an abnormal serotonergic system functioning. In this sense, it is well known that second and third weeks of life are linked to the development of conflict-based anxiety, and that a normal $5-\mathrm{HT}_{1 \mathrm{~A}}$ function is required to have a normal anxious phenotype $(8,25)$. In fact, a lower anxiety-like phenotype is observed in mice overexpressing postsynaptic $5-\mathrm{HT}_{1 \mathrm{~A}}$ receptors during early postnatal development (21), or after postsynaptic $5-\mathrm{HT}_{1 \mathrm{~A}} \mathrm{R}$ gainof-function in KO animals (8). However, no changes in anxiety-like responses in no 
1 previously stressed animals are found in $5-\mathrm{HT}_{1 \mathrm{~A}}$ heteroreceptor knock-out animals (25, 2 26).

3 One of the major findings of our study is the enhanced anxiety-like response (novelty 4 suppressed feeding and light/dark box tests) in these $5-\mathrm{HT}_{1 \mathrm{~A}} \mathrm{R}$ OE mice when pre5 exposed to an acute stressor (forced swimming). Indeed, it is well known that the acute 6 swim stress activates the serotonergic system (27), leading to a subsequent stress7 induced increase in serotonin $(28,29)$. However, other factors as corticosterone play 8 an important role in stress (30), and especially in our OE mice under acute stress 9 conditions, as discussed below. Regarding the stress-induced increase in the latency 10 to feed in the NSF, we cannot discard the influence of an appetite/motivational factor 11 associated to 5- $\mathrm{HT}_{1 \mathrm{~A}}$ receptor activation (31), since a lower drive to feed was confirmed 12 in the post-NSF consumption test. However, the lower food consumption appears to be 13 highly influenced by the high anxiety following the acute stressor elicited by these 5$14 \mathrm{HT}_{1 \mathrm{~A}} \mathrm{OE}$ mice, since the food consumed daily in their homecage was similar to their 15 WT counterparts.

\section{Blunted HPA in OE mice in response to stress}

Bearing in mind the increased anxiety-like response elicited in acutely stressed 5$\mathrm{HT}_{1 \mathrm{~A}} \mathrm{R}$ OE mice, we decided to check the status of the hypothalamic-pituitary-adrenal (HPA) axis. In non-stressed animals, corticosterone levels were higher in OE than in WT mice $(p<0.01)$. The exposure to acute stress induced an increase in serum corticosterone levels in WT animals $(p<0.001)$, but no changes in OE animals (Figure 3A). A two-way ANOVA analysis of serum corticosterone levels showed a significant effect of the stress $[F(1,33)=7.65, p<0.01]$, and the interaction genotype $x$ stress $[F(1,33)=15.95, p<0.001]$. Moreover, the effects of the circadian rhythm on the corticosterone levels differed between both groups, leading to a lower corticosterone peak in $5-\mathrm{HT}_{1 \mathrm{~A}} \mathrm{OE}$ animals $(\mathrm{p}<0.001)$ (Figure $\mathrm{S} 3$, Supporting Information).

We also evaluated the mRNA expression of MR and GR using qPCR (Figure 3B). MR mRNA expression was lower in OE mice compared to their WT counterparts (two-tailed t-test, t14=2.49; $p<0.05$ ), while GR mRNA expression was significantly higher in OE mice compared to WT animals (two-tailed t-test, $t 14=2.22 ; p<0.05$ ). The ratio MR/GR expression was significantly lower in OE mice compared to WT animals (two-tailed ttest, $\mathrm{t} 14=4.37 ; \mathrm{p}<0.001)$. 

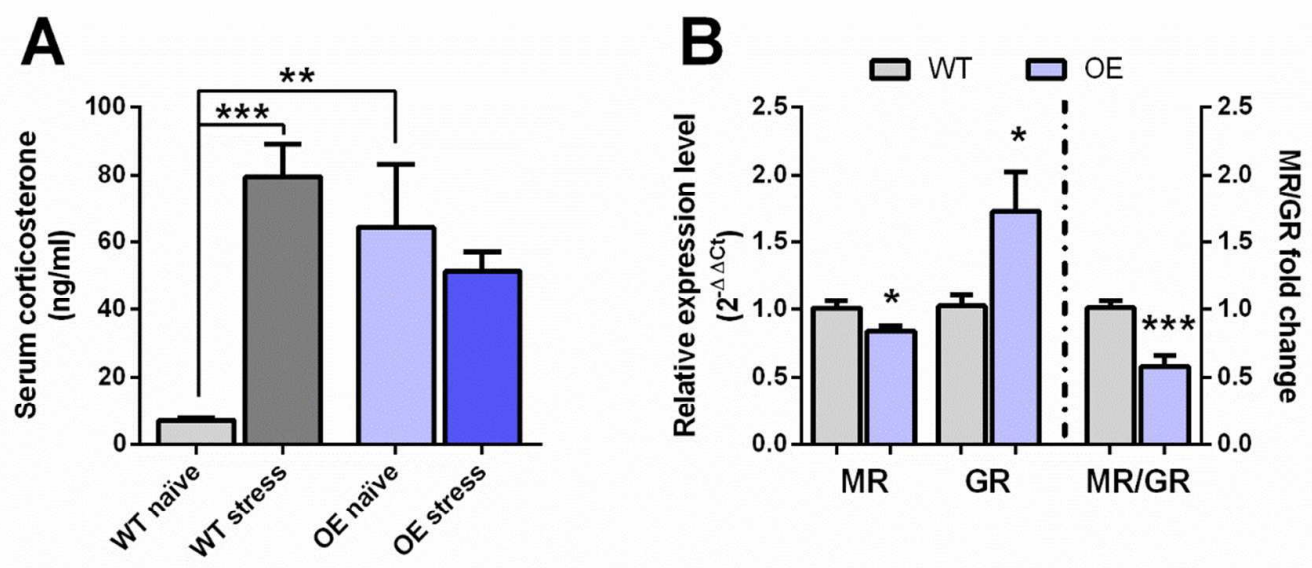

2

3 Figure 3. HPA response to stress in WT and OE $5-H T_{1 A} R$ mice. A) Serum 4 corticosterone levels in WT and 5-HT ${ }_{1 A} \mathrm{R}$ OE mice under basal conditions and after 5 acute stress. Serum corticosterone levels are expressed as $\mathrm{ng} / \mathrm{ml}$. Data are expressed 6 as the mean \pm SEM. Two-way ANOVA test followed by Bonferroni post-hoc test; $7{ }^{* *} p<0.01$ and ${ }^{* * *} p<0.001 . n=7-9$ animals per group. B) Corticosteroid mRNA receptor 8 expression in the hippocampus of $\mathrm{WT}$ and $5-\mathrm{HT}_{1 \mathrm{~A}} \mathrm{R}$ OE mice; MR expression, GR 9 expression and MR/GR expression ratio. Data are expressed as the mean \pm SEM. 10 Student's t-test, two-tailed; ${ }^{*} p<0.05,{ }^{* * *} p<0.001$. $n=6-8$ animals per group.

12 The enhanced anxious response to acute stress in postsynaptic $5-H T_{1 A} R$ OE mice is 13 associated with elevated basal corticosterone, without modifications of corticosterone 14 levels following stress (blunted HPA axis response) compared to their WT counterparts, in line with previous findings (30). These elevated basal corticosterone levels are in good agreement with that observed in animal models of stress $(9,32)$.

17 Furthermore, our $5-\mathrm{HT}_{1 \mathrm{~A}} \mathrm{R}$ OE mice present a lower diurnal variation of corticosterone 18 levels (32). This reduced corticosterone peak in 5- $\mathrm{HT}_{1 \mathrm{~A}} \mathrm{OE}$ mice parallels the findings reported in patients suffering from post-traumatic stress disorder $(33,34)$. Postsynaptic $5-\mathrm{HT}_{1 \mathrm{~A}} \mathrm{Rs}$, especially those localized in the paraventricular nucleus, are involved in stress regulation since their activation leads to increased corticosterone levels (35). The $5-\mathrm{HT}_{1 \mathrm{~A}} \mathrm{R}$ density is increased in the hypothalamus of these animals (23). However, we were not able to detect a significant change in the $5-\mathrm{HT}_{1 \mathrm{~A}} \mathrm{R}$ functionality probably 
1 due to the high basal $\left[{ }^{35} \mathrm{~S}\right] \mathrm{GTP} \gamma \mathrm{S}$ binding levels in this area. Therefore, it is difficult to

2 draw a conclusion about the role of $5-\mathrm{HT}_{1 \mathrm{~A}}$ hypothalamic receptors in the modulation of 3 corticosterone levels.

4 In the postsynaptic $5-\mathrm{HT}_{1 \mathrm{~A}} \mathrm{R}$ overexpressing mice, high basal corticosterone levels are 5 associated with lower levels of MR mRNA expression in the hippocampus, in good 6 accordance with previous studies $(9,10)$. The lower MR/GR mRNA expression ratio 7 observed in OE animals is also observed in animal models of stress (36), and contrast 8 with the higher ratio in animals with low-anxiety phenotype (37). This unbalanced 9 corticoid receptor expression is also present in rats with low $5-\mathrm{HT}_{1 \mathrm{~A}} \mathrm{R}$ expression in 10 DRN (38), mirroring the high post/presynaptic $5-\mathrm{HT}_{1 \mathrm{~A}} \mathrm{R}$ ratio present in our animals. 11 Interestingly, mice overexpressing MR in forebrain areas show an opposite behavior 12 with a less anxious phenotype induced by subsequent behavioral exposures (37). 13 Postsynaptic 5- $\mathrm{HT}_{1 \mathrm{~A}} \mathrm{R}$ OE mice also presented high levels of GR mRNA expression 14 similarly to animals with a high anxiety profile $(39,40)$, and a blunted HPA response 15 (40). It could be speculated that the high GR mRNA expression in OE animals may 16 result in a hyperactive negative feedback, and the subsequent impaired HPA response 17 following acute stress (41), though it requires further investigation (i.e.: dexamethasone 18 suppression test). A blunted response to stress has been reported after corticosterone 19 infusion in mPFCx (42), an area associated with stress habituation, suggesting that the 20 high basal corticosterone levels diminish the HPA stress response. Moreover, 21 increased activity in mPFCx, induced by the local administration of picrotoxin, is associated with a lower stress-induced corticosterone secretion (43).

\section{c-Fos activation in mPFCx induced by stress}

Taking in consideration the role of the mPFCx in stress-related responses, we next analyzed the neural activation level by means of c-Fos immunohistochemistry. Our results demonstrate that the c-Fos expression in mPFCx was increased in OE stressed animals $(p<0.001)$, while no changes were observed in the WT animals (Figure 4). A two-way ANOVA analysis of the c-Fos expression showed a significant effect of the genotype $[F(1,21)=8.90, p<0.01]$, the stress $[F(1,21)=39.39, p<0.001]$, and the interaction genotype $x$ stress $[F(1,21)=11.33, p<0.01]$. 

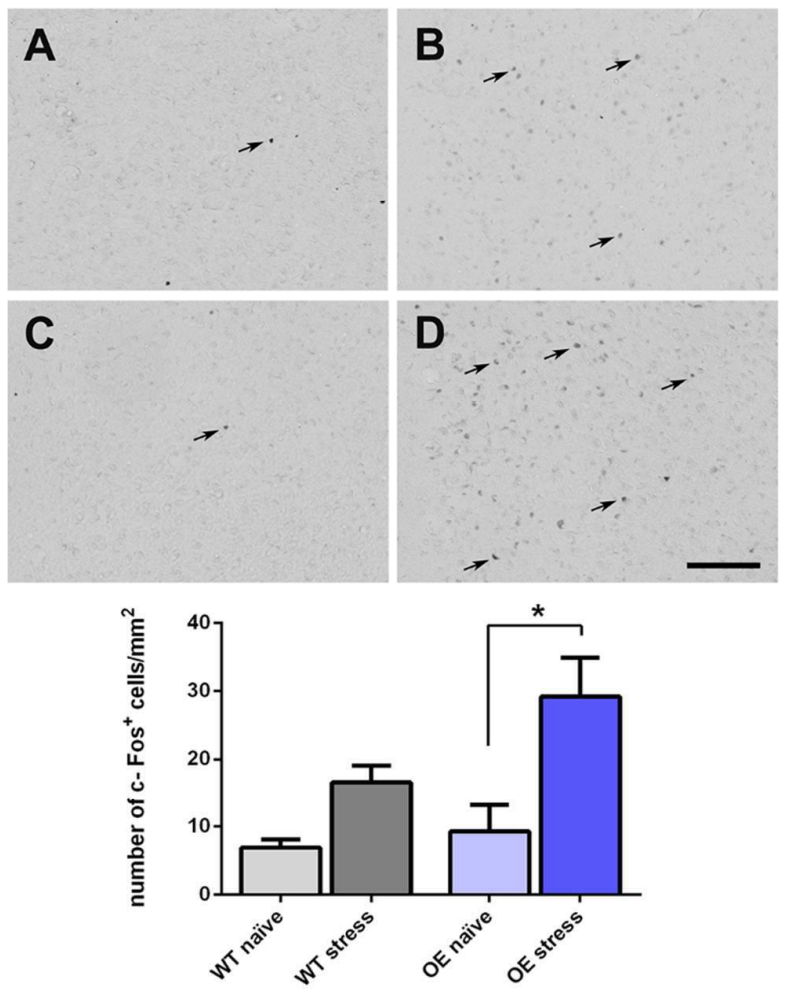

2 Figure 4. Activation of c-Fos in the medial prefrontal cortex of the WT and 5-HT ${ }_{1 \mathrm{~A}} \mathrm{OE}$ 3 mice under basal conditions and after acute stress. Two-way ANOVA followed by 4 Bonferroni post-hoc test; * $p<0.05$. Data expressed as the mean \pm SEM. $n=5-6$ animals 5 per group. Representative microphotographs are shown for c-Fos expression in: A) WT 6 naïve, B) WT stress, C) OE naïve, and D) OE stress. c-Fos positive cells are marked 7 with arrows. Bar: $100 \mu \mathrm{m}$.

9 In our study, the higher mPFCx c-Fos activation after stress may account for the absence of corticosterone secretion boost following stress (43). Moreover, the prefrontal cortex is involved in the regulation of stress as an area integrating 12 cognitive/affective information with HPA axis functioning $(44,45)$. Indeed, activation of 13 the prefrontal cortex, measured by increased c-Fos expression, is reported following stress-inducing procedures (i.e.: FST, immobilization) $(46,47,48)$, in line with our findings. However, other authors indicate that the $5-\mathrm{HT}_{1 \mathrm{~A}} \mathrm{R}$-mediated inhibition of $\mathrm{c}-\mathrm{Fos}$ expression in mPFCx is associated with a higher anxiety (49). It has been reported that

17 high anxious phenotype is associated to predominant $5-\mathrm{HT}_{1 \mathrm{~A}}$ activation on GABA 18 interneurons, leading to an increased pyramidal hyperactivity $(50,51)$. In good 
1 agreement, studies in GAD65 knock-out animals indicate increased fear and anxiety

2 behavior similar to models of posttraumatic stress disorder (52). Further experiments

3 are needed to clarify whether the overexpression of postsynaptic $5-\mathrm{HT}_{1 \mathrm{~A}} \mathrm{R}$ OE in these

4 mice leads to disturbances in the tone of GABAergic inhibition, and consequently,

5 increased pyramidal neuron activation, responsible for a higher level of anxiety.

6

\section{$7 \quad$ Lack of long-term potentiation (LTP) impairment in OE mice after acute stress}

8 Finally, taking into consideration the importance of LTP in stress response, we studied 9 the effect of stress on dorsal hippocampal CA1 LTP. To assess the effect of $5-H T_{1 A} R$ 10 overexpression on the hippocampal synaptic transmission and plasticity, we recorded 11 fEPSPs from hippocampal slices of WT and OE mice in non-stressed animals, and 12 after acute exposure to a stressing event. A theta burst stimulus was used to induce 13 LTP at the Schaffer collateral-CA1 pathway. No significant differences were found in 14 fEPSP amplitudes in the baseline of WT and OE mice. Comparison of LTP induction in 15 hippocampal slices of non-stressed WT and OE animals showed no differences in the 16 total LTP between both genotypes. As expected, LTP impairment was observed in 17 stressed WT mice $(p<0.01)$ (Figure 5A). By contrast, LTP measured in hippocampal 18 slices of stressed OE mice did not show significant differences compared to those not 19 subjected to a stressor (Figure 5B). 

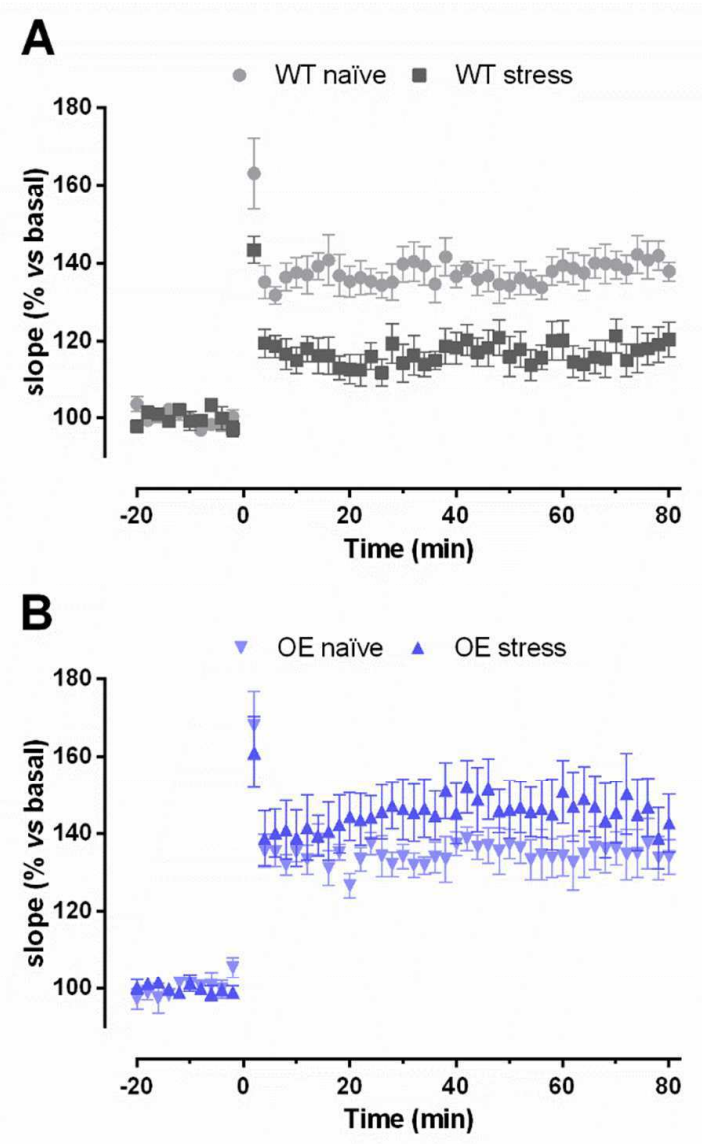

1

2 Figure 5. Lack of changes in hippocampal LTP after acute stress in 5- $\mathrm{HT}_{1 \mathrm{~A}} \mathrm{R}$ OE mice.

3 Time courses of the initial slope of fEPSPs recorded from the apical dendritic layer of

4 the CA1 region in hippocampal slices after stimulation of the Schaffer collateral-

5 commissural pathway at $30 \mathrm{~s}$ intervals. After $20 \mathrm{~min}$ of stable baseline recording, a

6 theta burst stimulus induced a robust and similar LTP in hippocampal slices of WT and

$7 \quad 5-\mathrm{HT}_{1 \mathrm{~A}} \mathrm{R}$ OE mice. The stress resulted in the significant down-regulation of the LTP in

8 WT animals $(p<0.01)(A)$, but not in OE mice $(B)$. Data are presented as mean \pm SEM

9 from one slice per animal $n=5-7$ per group.

11 These results demonstrate that the higher density and functionality of $5-\mathrm{HT}_{1 \mathrm{~A}} \mathrm{Rs}$ in the 12 dorsal hippocampus of OE mice does not affect LTP in basal conditions. Acute stress 13 exposure in WT animals induces a downregulation on the LTP in dorsal hippocampus, 14 as previously reported $(16,17,53,54)$, while does not induce changes in $5-\mathrm{HT}_{1 \mathrm{~A}} \mathrm{R}$ OE 15 mice. The LTP downregulation in dorsal hippocampus is associated to increased 
1 corticosterone levels $(16,54)$ after uncontrollable stress (54), acting through GR

2 receptors (55). Thus, our results strongly suggest that the absence of a stress-induced

3 increase in corticosterone levels in $5-\mathrm{HT}_{1 \mathrm{~A}} \mathrm{OE}$ mice is underlying the lack of LTP

4 downregulation following an acute stressing event in these animals.

5

6 Overall, mice overexpressing $5-\mathrm{HT}_{1 \mathrm{~A}} \mathrm{R}$ in postsynaptic areas showed exacerbated 7 anxious response to acute stress, a behavioral outcome associated with the inability to 8 modulate the HPA axis in response to stressors, increased prefrontal cortex activation, 9 and the lack of hippocampal LTP downregulation. A similar impaired stress response is 10 present in mice with high anxiety-related behavior and in some pathologies as in post11 traumatic stress disorder (PSTD) (56), and depression $(40,57)$. Therefore, a higher 5$12 \mathrm{HT}_{1 \mathrm{~A}} \mathrm{R}$ post/presynaptic ratio results in an impaired stress coping behavior that may 13 increase the susceptibility to develop stress-related emotional disorders.

\section{METHODS}

Animals

Permanent postsynaptic 5- $\mathrm{HT}_{1 \mathrm{~A}}$-receptor overexpressing (OE) mice strain and their wild-type (WT) counterparts were generated as previously indicated $(21,22)$. These mice strain was created on an out-bred NMRI genetic background. They exhibit a higher $5-\mathrm{HT}_{1 \mathrm{~A}}$ receptor density in hippocampus, cortex, amygdala, and hypothalamus, areas in which these receptors are located at the postsynaptic level. However, no changes are found in the density of $5-\mathrm{HT}_{1 \mathrm{~A}}$ autoreceptors in the raphe nuclei $(22,23)$. Male mice (10-14 weeks) were grouped housed $(n=4-5)$ under controlled conditions $\left(22 \pm 1^{\circ} \mathrm{C} ; 12 \mathrm{~h}\right.$ light/dark cycle) with food and water ad libitum. All procedures were carried out with the previous approval of the Animal Care Committee of the University of Cantabria and according to the Spanish legislation (RD 53/2013) and the European Communities Council Directive (2010/63/UE) on "Protection of Animals Used in Experimental and Other Scientific Purposes".

Two different types of studies were designed. First, different sets of WT and OE animals were used in autoradiography ( $n=5-6$ per group) and qPCR assays ( $n=6-8$ per group). Second, four experimental groups (WT naïve, WT stress, OE naïve, and OE 
1 stress mice) were used to assess the effect of acute stress in the following 2 experimental procedures: behavioral testing ( $n=6-10$ per group), serum corticosterone 3 measurement ( $n=5-9$ per group), c-Fos immunohistochemistry ( $n=5-6$ per group), and 4 electrophysiology studies ( $n=5-7$ per group). A different set of animals was used for 5 each experimental technique.

6 Acute stress protocol: a single forced swimming session was used as acute stressor. 7 Mice were placed in swimming tanks $12 \mathrm{~cm}$ in diameter and $24 \mathrm{~cm}$ tall. The tank was 8 filled with enough water at $25-27^{\circ} \mathrm{C}$ so that the mice could not touch the bottom. Each 9 mouse was placed individually in the swimming tank for a single $5 \mathrm{~min}$ session, gently 10 dried up using a paper towel, and immediately used in the different experimental 11 procedures.

12 Experimental design for "stress" studies (see chronogram in Figure 6): naïve and 13 stressed animals were subjected to a battery of behavioral and neurochemical 14 analyses. A) light/dark box and novelty suppressed feeding tests, with a one-week 15 delay between both; B) blood extraction for serum corticosterone determination; C) animal perfusion 2 hours after the stressor for c-Fos immunohistochemistry studies; and $\mathrm{D}$ ) in vivo recording of long-term potentiation in hippocampal slices.
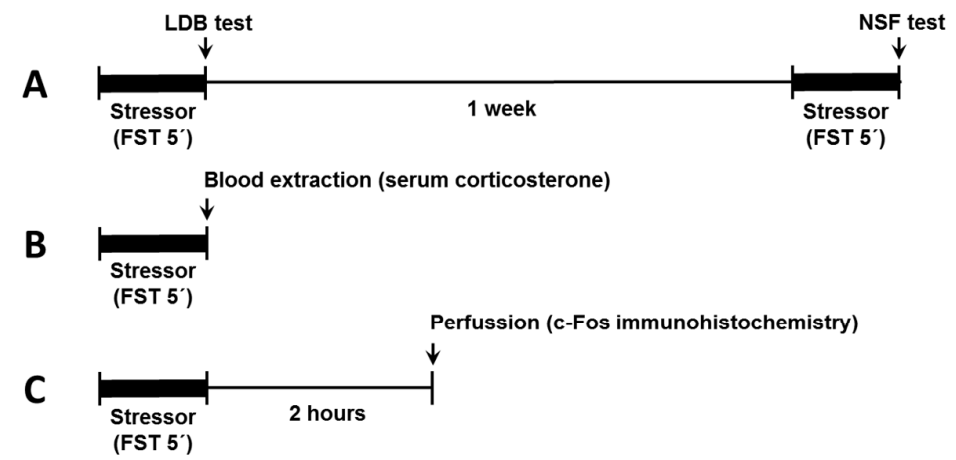

19 Figure 6. Experimental timeline for the acute stressing procedure (5 min forced 20 swimming session), in the stressed groups. A) Light/dark box (LDB) and novelty 21 suppressed feeding (NSF) tests; B) blood sampling immediately after the acute stress; $22 \mathrm{C}$ ) perfusion $2 \mathrm{~h}$ after the stressing event in the c-Fos immunohistochemical assays; 
1 and D) hippocampal sectioning immediately after the 5 min swim session for the long

2 term potentiation experiments.

4 Autoradiography for $5-\mathrm{HT}_{1 \mathrm{~A}}$ receptor function

5 Experiments were performed following a previously described protocol (58). Sections 6 were pre-incubated for $30 \mathrm{~min}$ at $25^{\circ} \mathrm{C}$ in a buffer containing $50 \mathrm{mM}$ Tris- $\mathrm{HCl}, 0.2 \mathrm{mM}$ 7 EGTA, $3 \mathrm{mM} \mathrm{MgCl}, 100 \mathrm{mM} \mathrm{NaCl}, 1 \mathrm{mM}$ DTT and $2 \mathrm{mM}$ GDP (pH 7.7), and 8 subsequently incubated for $2 \mathrm{~h}$ at $25^{\circ} \mathrm{C}$ in the same buffer containing $3 \mathrm{mU} / \mathrm{ml}$ 9 adenosine deaminase and $0.04 \mathrm{nM}\left[{ }^{35}\right.$ S]guanosine-5-O-(3-thio) triphosphate (GTP $\gamma$; 10 PerkinElmer Inc., Waltham, MA, USA). Consecutive sections were incubated with 10 $11 \mu \mathrm{M}$ of the selective $5-\mathrm{HT}_{1 \mathrm{~A}} \mathrm{R}$ agonist ( \pm )-8-hydroxy-N,N-dipropyl-2-aminotetralin (8-OH12 DPAT; Sigma-Aldrich, Spain) alone or in the presence of $10 \mu \mathrm{M}$ of the selective 5$13 \mathrm{HT}_{1 \mathrm{~A}} \mathrm{R}$ antagonist WAY100635. Non-specific binding was determined in the presence 14 of $10 \mu \mathrm{M} \mathrm{GTP} \gamma \mathrm{S}$. After the incubation, the sections were washed twice for 15 min in 50 $15 \mathrm{mM}$ Tris- $\mathrm{HCl}$ buffer $(\mathrm{pH} 7.4)$ at $4^{\circ} \mathrm{C}$, rinsed in distilled cold water and cold air dried. 16 Sections were exposed to radiation-sensitive films (BioMax® MR film, Sigma-Aldrich, 17 San Luis, MI, USA) together with ${ }^{14} \mathrm{C}$-polymer standards (Amersham, UK) for 2 days at $184^{\circ} \mathrm{C}$. 8-OH-DPAT stimulated values are represented as percentage versus basal $19(100 \%)$.

Behavioral tests

Light/dark box test: The light/dark box test was performed in an arena formed by two equally sized compartments $(15 \mathrm{~cm}$ wide $\times 30 \mathrm{~cm}$ long $\times 20 \mathrm{~cm}$ high) separated by an opening located centrally at floor level $(6 \mathrm{~cm}$ wide $\times 6 \mathrm{~cm}$ high) (59). A dark compartment had black walls covered with a lid. The other compartment (not covered) had see-through walls and was lit by a light bulb (400 lux). Mice were placed in one corner of the light compartment. The latency of the first entry, time spent, number of entries into the brightly lit compartment, and total distance traveled in both compartments, were recorded during 5 min testing session using Any-maze Video30 Tracking software (Stoelting Co., Wood Dale, IL, USA). The anxiety level was represented as the ratio of the time spent in the light vs the dark compartment. 
Novelty suppressed feeding: This test was performed 7 days after the light/dark

c-Fos immunohistochemistry

Mice were anesthetized with an injection of sodium pentobarbital (100 mg/kg, i.p.) and transcardially perfused with $4 \%$ paraformaldehyde in PBS. Brains were post-fixed and cryoprotected with $30 \%$ sucrose. Serial coronal sections $(40 \mu \mathrm{m})$ of the brains were obtained. Sections were treated with $0.3 \% \mathrm{H}_{2} \mathrm{O}_{2}$ in phosphate-buffered saline (PBS) for 10 min and blocked with $0.2 \%$ Triton $\mathrm{X}-100$ and $2 \%$ normal donkey serum at room temperature for $1 \mathrm{~h}$. Sections were incubated with rabbit anti c-Fos primary antibody (1:1000; Santa Cruz Biotechnology) in PBS containing 3\% normal donkey serum, at $4^{\circ} \mathrm{C}$ overnight. Sections were washed in PBS-T, and incubated with a biotinylated donkey anti-rabbit IgG secondary antibody (1:200; Jackson ImmunoResearch Laboratories, Inc., West Grove, PA, USA) and amplified with avidin-biotin complex (Vector Laboratories, Burlingame, CA, USA). c-Fos positive cells were labeled using diaminobenzidine $(\mathrm{DAB})+\mathrm{Ni}$ as chromogen (Vector Laboratories).

c-Fos-containing cells were counted in the medial prefrontal cortex including prelimbic and infralimbic regions (from 1.98 to $1.70 \mathrm{~mm}$ relative to Bregma) (61). Nuclei counting was performed by a blind observer to experimental groups. Data are presented as cFos positive cells per area $\left(\mathrm{mm}^{2}\right)$.

Microscope image acquisition

c-Fos immunohistochemistry was visualized using a brightfield microscope Zeiss Axio Scope.A1, using a 10x magnification, and 0.25 numerical aperture of the objective lenses. The image acquisition was performed using a Zeiss AxioCam HRc camera, and 
1 the acquisition software used was Micro-Manager (version 1.4.22) (62). The images 2 were processed using an Adobe Photoshop CC software (version 14.0) (Adobe 3 Systems Software Ireland Ltd., Ireland).

4

5 Serum corticosterone levels measurement

6 Blood samples were collected between 9 and 11 a.m. in the different experimental 7 groups (WT and OE, stressed and non-stressed). For the corticosterone variation 8 during the day, blood samples were collected every 4 hours in WT and OE non9 stressed animal groups, starting at 10 a.m. Mice were deeply anesthetized with sodium pentobarbital (40 mg/kg, i.p.) to avoid procedure stress. The mice tails were cut and whole blood was collected in tubes ( $100 \mu$ volume approximately). The blood was led to clotting during 20-30 minutes and centrifuged twice at $2000 \mathrm{xg}$ for 10 minutes to completely remove the debris. The serum was stored at $-20^{\circ} \mathrm{C}$ until use. The corticosterone amount present in the serum samples was measured using a corticosterone ELISA Kit (Abcam plc, UK) as indicated by the supplier. Briefly, serum samples were diluted 1:5 and incubated together with biotinylated corticosterone in the plate wells provided in the kit during 2 hours at room temperature. Then, the wells were washed and added streptavidin-peroxidase conjugate and incubated for $30 \mathrm{~min}$. After that, the plate was washed and incubated for $30 \mathrm{~min}$ with the chromogen substrate. The reaction was stopped and the absorbance was measured at $450 \mathrm{~nm}$. The standard curve data were fitted to a four-parameter logistic nonlinear regression curve.

\section{Quantitative PCR}

Mice were killed by decapitation, the brains rapidly removed from the skulls, and the hippocampi dissected, immediately frozen and stored at $-80^{\circ} \mathrm{C}$ until used. Total RNA and whole protein homogenate were extracted using Tripure ${ }^{\mathrm{TM}}$ Isolation Reagent (Sigma-Aldrich) according to the manufacturer's instructions.

Once purified, the quality and concentration of the sample were tested measuring the absorbance (260/280 nm) with the NanoDrop 1000 Spectrophotometer (Thermo Fisher Scientific, Waltham, MA, USA) and the Agilent 2100 Bioanalyzer (Agilent Technologies, Santa Clara, CA, USA). RNA was reverse transcribed to cDNA using the High Capacity 
1 cDNA Reverse Transcription kit (Applied Biosystems, Foster City, CA, USA). Real-time 2 quantitative polymerase chain reaction (qPCR) was performed in triplicate using gene3 specific primers and SYBR® Green on an ABI PRISM 7500 real-time thermal cycler 4 (Applied Biosystems). Oligonucleotide primers were designed using Primer Express 5 software (Applied Biosystems). The primer sequences and the GenBank accession 6 numbers are given in Table 1.

7 Table 1. Primers used in qPCR studies and GenBank accession numbers.

\begin{tabular}{|l|l|l|l|}
\hline Gene & Forward & Reverse & NCBI reference \\
\hline $\begin{array}{l}\text { MR } \\
(\mathrm{Nr3c2})\end{array}$ & 5'-GGCTACCACAGTCTCCCTGA-3' & 5'-ACGTTGACAATCTCCATGTAG-3' & NM_001083906.1 \\
\hline $\begin{array}{l}\text { GR } \\
(\mathrm{Nr3c1})\end{array}$ & 5'-TGGGACTGTATATGGGAGAG-3' & 5'-GGTTTGCAATGCTTTCTTCC-3' & NM_008173.3 \\
\hline GAPDH & 5'-ACAGTCCATGCCATCACTGCC-3' & 5'-GCCTGCTTCACCACCTTCTTG-3' & NM_008084 \\
\hline $\begin{array}{l}\text { 18S } \\
(\mathrm{Rn} 18 \mathrm{~s})\end{array}$ & 5'-CTTAGAGGGACAAGTGGCG-3' & 5'-ACGCTGAGCCAGTCAGTGTA-3' & NR_003278 \\
\hline Actb & 5'-CTCTGGCTCCTAGCACCATGAAGA-3' & 5'-GTAAAACGCAGCTCAGTAACAGTCCG-3' & NM_007393 \\
\hline \multicolumn{1}{|l|}{8} & \multicolumn{2}{|l}{} \\
\hline
\end{tabular}

9 Relative changes in the expression of the target genes were determined using the 10 following equation: fold change $=2^{-\Delta \Delta \mathrm{Ct}}$, where $\Delta \mathrm{Ct}=(\mathrm{Ct}$ target $-\mathrm{Ct} 18 \mathrm{~S}$ rRNA) and $11 \Delta \Delta \mathrm{Ct}=\Delta \mathrm{Ct}$ (for the experimental condition) $-\Delta \mathrm{Ct}$ (for the control condition) (63). These 12 experiments were carried out according to the minimum information for publication of 13 quantitative real-time PCR experiments (MIQE) guidelines (64).

15 Long-term potentiation (LTP)

16 Mice were decapitated and the brains were rapidly removed. The hippocampi were 17 dissected and $400 \mu \mathrm{m}$ slices were cut with a tissue chopper (65). Slices were allowed 18 to recover for at least $1 \mathrm{~h}$ in an interface chamber at room temperature with artificial 19 CSF containing the following: $120 \mathrm{mM} \mathrm{NaCl}, 3.5 \mathrm{mM} \mathrm{KCl}, 2.5 \mathrm{mM} \mathrm{CaCl}_{2}, 1.3 \mathrm{mM}$ $20 \mathrm{MgSO}_{4}, 1.25 \mathrm{mM} \mathrm{NaH}_{2} \mathrm{PO}_{4}, 26 \mathrm{mM} \mathrm{NaHCO}_{3}$, and $10 \mathrm{mM}$ D-glucose (saturated with $2195 \% \mathrm{O}_{2}$ and $5 \% \mathrm{CO}_{2}$ ). Field EPSPs (fEPSPs) were recorded from the CA1 stratum 
1 radiatum of dorsal hippocampus with a glass micropipette (1-4 M $\Omega$ ) containing $2 \mathrm{M}$

$2 \mathrm{NaCl}$ and evoked by stimulation of the Schaffer collaterals with insulated bipolar

3 platinum/iridium electrodes $>500 \mu \mathrm{m}$ away from the recording electrode. The stimulus

4 strength was adjusted to evoke fEPSPs equal to $50 \%$ of the relative maximum

5 amplitude without superimposed population spike. After stable baseline recordings

$6 \quad(100 \mu$ s pulse duration, $0.033 \mathrm{~Hz})$, LTP was induced by theta burst stimulation (10

7 trains of five pulses at $100 \mathrm{~Hz}$ and intervals of $200 \mathrm{~ms}$ ). The duration of the stimulation

8 pulses was doubled during tetanus. fEPSPs were amplified, bandpass filtered ( $1 \mathrm{~Hz}$ to

$91 \mathrm{kHz}$ ), and stored in a computer using the Spike 2 program (Cambridge Electronic

10 Design, Cambridge, UK). For the analysis, fEPSP slopes were expressed as a

11 percentage of the baseline values recorded.

13 Data analysis

14 Results are shown as mean \pm standard error of the mean. The statistical analysis of the 15 results was performed using Student's t-test or two-way ANOVA (genotype and stress 16 as main factors) followed by Student-Newman-Keuls posthoc test. The statistical 17 analysis in the electrophysiological experiments was performed using repeated18 measures (RM) multivariate ANOVA (MANOVA) (time $x$ stress $x$ genotype). The 19 statistical analysis test and the number of animals used for each experimental set are 20 indicated in the results section and figure legends. The level of significance was set at $21 \mathrm{p}<0.05$. Graphs and the statistical analyses were calculated using the GraphPad Prism 225.01 software (GraphPad Software, GraphPad, USA), or SPSS for Windows version 2318.0.

SUPPORTING INFORMATION

Table S1. Absolute values (nCi/g tissue) of basal $\left[{ }^{35} \mathrm{~S}\right] \mathrm{GTP} \gamma \mathrm{S}$ binding.

27 Figure S1. Total distance traveled in the light/dark box test.

Figure S2. Food eaten in the novelty suppressed feeding post-test.

\section{ABBREVIATIONS:}


$15-\mathrm{HT}_{1 \mathrm{~A}}$ receptor $\left(5-\mathrm{HT}_{1 \mathrm{~A}} \mathrm{R}\right)$ overexpressing (OE) mice, forced swimming test (FST),

2 open field (OF), novelty suppressed feeding (NSF) test, mineralocorticoid receptor

3 (MR), glucocorticoid receptor (GR), long-term potentiation (LTP).

4

\section{AUTHOR INFORMATION}

6 Author contributions:

7 FP-C designed and performed experiments, analyzed and interpreted data, and drafted 8 the manuscript. RV performed electrophysiological experiments, analyzed and 9 interpreted data. AD designed experiments, analyzed and interpreted data, and drafted 10 the manuscript. EG-M performed immunohistochemistry studies. RL performed the 11 corticosterone measurement and quantitative PCR experiments. EC designed 12 experiments, analyzed and interpreted data, and drafted the manuscript. RH performed 13 the behavioral studies. HF performed the critical revision of the manuscript. BB 14 analyzed and interpreted the data, and drafted the manuscript. JB analyzed and 15 interpreted the data, and drafted the manuscript. BR performed the corticosterone 16 measurement. BC-F performed the critical revision of the manuscript. AP designed 17 experiments and performed the critical revision of the manuscript.

18 Funding sources:

19 This research was supported by Spanish Ministry of Economy and Competitiveness 20 (SAF2011-25020 and SAF2015-67457-R), Instituto de Salud Carlos III (FIS Grant 21 PI13-00038) co-funded by the European Regional Development Fund ('A way to build 22 Europe') and Centro de Investigación Biomédica en Red de Salud Mental 23 (CIBERSAM).

24 Conflict of interest:

25 The authors declare no competing financial interests.

\section{ACKNOWLEDGMENTS}


1 This research was supported by Spanish Ministry of Economy and Competitiveness

2 (SAF2011-25020 and SAF2015-67457-R), Instituto de Salud Carlos III (FIS Grant 3 PI13-00038) co-funded by the European Regional Development Fund ('A way to build 4 Europe') and Centro de Investigación Biomédica en Red de Salud Mental 5 (CIBERSAM).

6 We thank the technical assistance of Raquel Gutierrez-Lanza, Helena Blanco, and 7 Alicia Martín. The authors would like to thank Professor Elsa Valdizán (deceased on 8 18th March 2016) for her contribution and support; her memory will always be with us.

\section{REFERENCES}

1. Lucki, I. (1998) The spectrum of behaviors influenced by serotonin. Biol. Psychiatry 44, 151-162.

2. Pazos, A., and Palacios, J. M. (1985) Quantitative autoradiographic mapping of serotonin receptors in the rat brain. I. Serotonin-1 receptors. Brain Res. 346, 205230.

3. Overstreet, D. H., Commissaris, R. C., De La Garza, R. $2^{\text {nd }}$., File, S. E., Knapp, D. J., and Seiden, L. S. (2003) Involvement of 5-HT1A receptors in animal tests of anxiety and depression: evidence from genetic models. Stress 6, 101-110.

4. Neumeister, A., Bain, E., Nugent, A. C., Carson, R. E., Bonne, O., Luckenbaugh, D. A., Eckelman, W., Herscovitch, P., Charney, D. S., and Drevets, W. C. (2004) Reduced serotonin type $1 \mathrm{~A}$ receptor binding in panic disorder. J. Neurosci. 24, 589-591.

5. Celada, P., Bortolozzi, A., and Artigas, F. (2013) Serotonin 5-HT1A receptors as targets for agents to treat psychiatric disorders: rationale and current status of research. C.N.S. Drugs 27, 703-716.

6. Savitz, J., Lucki, I., and Drevets, W. C. (2009) 5-HT(1A) receptor function in major depressive disorder. Prog. Neurobiol. 88, 17-31.

7. Akimova, E., Lanzenberger, R., and Kasper, S. (2009) The serotonin-1A receptor in anxiety disorders. Biol. Psychiatry 66, 627-635.

8. Gross, C., Zhuang, X., Stark, K., Ramboz, S., Oosting, R., Kirby, L., Santarelli, L., Beck, S., and Hen, R. (2002) Serotonin1A receptor acts during development to establish normal anxiety-like behaviour in the adult. Nature 416, 396-400. 
9. Lopez, J. F., Chalmers, D. T., Little, K. Y., and Watson, S. J. (1998) A.E. Bennett Research Award. Regulation of serotonin1A, glucocorticoid, and mineralocorticoid receptor in rat and human hippocampus: implications for the neurobiology of depression. Biol. Psychiatry 43, 547-573.

10. Karten, Y. J., Nair, S. M., van Essen, L., Sibug, R., and Joels, M. (1999) Long-term exposure to high corticosterone levels attenuates serotonin responses in rat hippocampal CA1 neurons. Proc. Natl. Acad. Sci. U. S. A. 96, 13456-13461.

11. Gotlib, I. H., Joormann, J., Minor, K. L., Hallmayer, J. (2008) HPA axis reactivity: a mechanism underlying the associations among 5-HTTLPR, stress, and depression. Biol Psychiatry 63, 847-851.

12. Pariante, C. M., Lightman, S. L. (2008) The HPA axis in major depression: classical theories and new developments. Trends Neurosci 31, 464-468.

13. de Kloet, E. R., Joels, M., and Holsboer, F. (2005) Stress and the brain: from adaptation to disease. Nat. Rev. Neurosci. 6, 463-475.

14. Mizoguchi, K., Ishige, A., Aburada, M., and Tabira, T. (2003) Chronic stress attenuates glucocorticoid negative feedback: involvement of the prefrontal cortex and hippocampus. Neuroscience 119, 887-897.

15. Jarcho, M. R., Slavich, G. M., Tylova-Stein, H., Wolkowitz, O. M., Burke, H. M. (2013) Dysregulated diurnal cortisol pattern is associated with glucocorticoid resistance in women with major depressive disorder. Biol Psychol 93, 150-158.

16. Maggio, N., Segal, M. (2007) Striking variations in corticosteroid modulation of long-term potentiation along the septotemporal axis of the hippocampus. $J$ Neurosci. 27, 5757-5765.

17. Krugers, H. J., Alfarez, D. N., Karst, H., Parashkouhi, K., van Gemert, N., and Joels, M. (2005) Corticosterone shifts different forms of synaptic potentiation in opposite directions. Hippocampus 15, 697-703.

18. Pavlides, C., Watanabe, Y., Magarinos, A. M., and McEwen, B. S. (1995) Opposing roles of type I and type II adrenal steroid receptors in hippocampal longterm potentiation. Neuroscience 68, 387-394.

19. Joels, M., Velzing, E., Nair, S., Verkuyl, J. M., and Karst, H. (2003) Acute stress increases calcium current amplitude in rat hippocampus: temporal changes in physiology and gene expression. Eur. J. Neurosci. 18, 1315-1324.

20. Joels, M. (2008) Functional actions of corticosteroids in the hippocampus. Eur. J. Pharmacol. 583, 312-321. 
21. Kusserow, H., Davies, B., Hörtnagl, H., Voigt, I., Stroh, T., Bert, B., Deng, D. R., Fink, H., Veh, R. W., and Theuring, F. (2004) Reduced anxiety-related behaviour in transgenic mice overexpressing serotonin 1A receptors. Brain Res. Mol. Brain Res. 129, 104-116.

22. Bert, B., Fink, H., Hortnagl, H., Veh, R. W., Davies, B., Theuring, F., and Kusserow, $H$. (2006) Mice over-expressing the 5-HT(1A) receptor in cortex and dentate gyrus display exaggerated locomotor and hypothermic response to $8-\mathrm{OH}-$ DPAT. Behav. Brain Res. 167, 328-341.

23. Günther, L., Rothe, J., Rex, A., Voigt, J. P., Millan, M. J., Fink, H., and Bert, B. (2011) 5-HT(1A)-receptor over-expressing mice: genotype and sex dependent responses to antidepressants in the forced swim-test. Neuropharmacology 61, 433-441.

24. Richardson-Jones, J. W., Craige, C. P., Guiard, B. P., Stephen, A., Metzger, K. L., Kung, H. F., Gardier, A. M., Dranovsky, A., David, D. J., Beck, S. G., Hen, R., and Leonardo, E. D. (2010) 5-HT1A autoreceptor levels determine vulnerability to stress and response to antidepressants. Neuron 65, 40-52.

25. Richardson-Jones, J. W., Craige, C. P., Nguyen, T. H., Kung, H. F., Gardier, A. M., Dranovsky, A., David, D. J., Guiard, B. P., Beck, S. G., Hen, R., and Leonardo, E. D. (2011) Serotonin-1A autoreceptors are necessary and sufficient for the normal formation of circuits underlying innate anxiety. J. Neurosci. 31, 6008-6018.

26. Garcia-Garcia, A. L., Meng. Q., Canetta, S., Gardier, A. M., Guiard, B.P., Kellendonk, C., Dranovsky, A., Leonardo, E. D. (2017) Serotonin Signaling through Prefrontal Cortex 5-HT1A Receptors during Adolescence Can Determine Baseline Mood-Related Behaviors. Cell Rep. 18, 1144-1156.

27. Roche, M., Commons, K. G., Peoples, A., Valentino, R. J. (2003) Circuitry underlying regulation of the serotonergic system by swim stress. J. Neurosci. 23, 970-977.

28. File, S. E., Gonzalez, L. E., and Andrews, N. (1996) Comparative study of pre- and postsynaptic 5-HT1A receptor modulation of anxiety in two ethological animal tests. J. Neurosci. 16, 4810-4815.

29. Stefański, R., Pałejko, W., Bidziński, A., Kostowski, W. and Płaźnik, A. (1993) Serotonergic innervation of the hippocampus and nucleus accumbens septi and the anxiolytic-like action of midazolam and 5-HT1A receptor agonists. Neuropharmacology 32, 977-985.. 
30. Kinlein, S. A., Wilson, C. D., Karatsoreos, I. N. (2015) Dysregulated hypothalamicpituitary-adrenal axis function contributes to altered endocrine and neurobehavioral responses to acute stress. Front Psychiatry 6, 31.

31. Brosda, J., Muller, N., Bert, B., and Fink, H. (2015) Modulatory Role of Postsynaptic 5-Hydroxytryptamine Type 1A Receptors in (+/-)-8-Hydroxy-N,Ndipropyl-2-aminotetralin-Induced Hyperphagia in Mice. A.C.S. Chem. Neurosci. 6, 1176-1185.

32. Christiansen, S. L., Højgaard, K., Wiborg, O., Bouzinova, E. V. (2016) Disturbed diurnal rhythm of three classical phase markers in the chronic mild stress rat model of depression. Neurosci. Res. 110, 43-48.

33. Neylan, T. C., Brunet, A., Pole, N., Best, S. R., Metzler, T. J., Yehuda, R., Marmar, C. R. (2005) PTSD symptoms predict waking salivary cortisol levels in police officers. Psychoneuroendocrinology 30, 373-381.

34. de Kloet, C. S., Vermetten, E., Heijnen, C. J., Geuze, E., Lentjes, E. G., Westenberg, H. G. (2007) Enhanced cortisol suppression in response to dexamethasone administration in traumatized veterans with and without posttraumatic stress disorder. Psychoneuroendocrinology 32, 215-226.

35. Vicentic, A., Li, Q., Battaglia, G., and Van de Kar, L. D. (1998) WAY-100635 inhibits 8-OH-DPAT-stimulated oxytocin, ACTH and corticosterone, but not prolactin secretion. Eur. J. Pharmacol. 346, 261-266.

36. Zhe, D., Fang, H., and Yuxiu, S. (2008) Expressions of hippocampal mineralocorticoid receptor (MR) and glucocorticoid receptor (GR) in the singleprolonged stress-rats. Acta Histochem. Cytochem. 41, 89-95.

37. Rozeboom, A. M., Akil, H., and Seasholtz, A. F. (2007) Mineralocorticoid receptor overexpression in forebrain decreases anxiety-like behavior and alters the stress response in mice. Proc. Natl. Acad. Sci. U. S. A. 104, 4688-4693.

38. Calvo, N., Cecchi, M., Kabbaj, M., Watson, S. J., and Akil, H. (2011) Differential effects of social defeat in rats with high and low locomotor response to novelty. Neuroscience 183, 81-89.

39. Wei, Q., Lu, X. Y., Liu, L., Schafer, G., Shieh, K. R., Burke, S., Robinson, T. E., Watson, S. J., Seasholtz, A. F., and Akil, H. (2004) Glucocorticoid receptor overexpression in forebrain: a mouse model of increased emotional lability. Proc. Natl. Acad. Sci. U. S. A. 101, 11851-11856.

40. Sotnikov, S., Wittmann, A., Bunck, M., Bauer, S., Deussing, J., Schmidt, M., Touma, C., Landgraf, R., and Czibere, L. (2014) Blunted HPA axis reactivity 
reveals glucocorticoid system dysbalance in a mouse model of high anxiety-related behavior. Psychoneuroendocrinology 48, 41-51.

41. Feldman, S., and Weidenfeld, J. (1999) Glucocorticoid receptor antagonists in the hippocampus modify the negative feedback following neural stimuli. Brain Res.

4 821, 33-37.

42. Diorio, D., Viau, V., and Meaney, M. J. (1993) The role of the medial prefrontal cortex (cingulate gyrus) in the regulation of hypothalamic-pituitary-adrenal responses to stress. J. Neurosci. 13, 3839-3847.

43. Weinberg, M. S., Johnson, D. C., Bhatt, A. P., and Spencer, R. L. (2010) Medial prefrontal cortex activity can disrupt the expression of stress response habituation. Neuroscience 168, 744-756.

44. Radley, J. J., Arias, C. M., Sawchenko, P. E. (2006) Regional differentiation of the medial prefrontal cortex in regulating adaptive responses to acute emotional stress. J Neurosci 26, 12967-12976.

45. Jankord, R., Herman, J. P. (2008) Limbic regulation of hypothalamo-pituitaryadrenocortical function during acute and chronic stress. Ann N Y Acad Sci 1148, 64-73.

46. Ons, S., Martí, O., Armario, A. (2004) Stress-induced activation of the immediate early gene Arc (activity-regulated cytoskeleton-associated protein) is restricted to telencephalic areas in the rat brain: relationship to c-fos mRNA. J Neurochem 89, 1111-1118.

47. Muigg, P., Scheiber, S., Salchner, P., Bunck, M., Landgraf, R., Singewald. N. (2009) Differential stress-induced neuronal activation patterns in mouse lines selectively bred for high, normal or low anxiety. PLoS One 4, :e5346.

48. Pizzo, R., O'Leary, O. F., Cryan, J. F. (2017) Elucidation of the neural circuits activated by a GABAB receptor positive modulator: Relevance to anxiety. Neuropharmacology pii: S0028-3908(17)30352-0.

49. Soiza-Reilly, M., Goodfellow, N. M., Lambe, E. K., and Commons, K. G. (2015) Enhanced 5-HT1A receptor-dependent feedback control over dorsal raphe serotonin neurons in the SERT knockout mouse. Neuropharmacology 89, $185-$ 192.

50. Holmes, A. (2008) Genetic variation in cortico-amygdala serotonin function and risk for stress-related disease. Neurosci. Biobehav. Rev. 32, 1293-1314. 
51. Albert, P. R., Vahid-Ansari, F., and Luckhart, C. (2014) Serotonin-prefrontal cortical circuitry in anxiety and depression phenotypes: pivotal role of pre- and post-synaptic 5-HT1A receptor expression. Front. Behav. Neurosci. 8, 199.

52. Stork, O., Ji, F. Y., Kaneko, K., Stork, S., Yoshinobu, Y., Moriya, T., Shibata, S., and Obata, K. (2000) Postnatal development of a GABA deficit and disturbance of neural functions in mice lacking GAD65. Brain Res. 865, 45-58.

53. Alfarez, D. N., Wiegert, O., Joëls, M., Krugers, H. J. (2002) Corticosterone and stress reduce synaptic potentiation in mouse hippocampal slices with mild stimulation. Neuroscience. 115, 1119-1126.

54. Kavushansky, A., Vouimba, R. M., Cohen, H., Richter-Levin, G. (2006) Activity and plasticity in the CA1, the dentate gyrus, and the amygdala following controllable vs. uncontrollable water stress. Hippocampus 16, 35-42.

55. Avital, A., Segal, M., Richter-Levin, G. (2006) Contrasting roles of corticosteroid receptors in hippocampal plasticity. J Neurosci. 26, 9130-9134.

56. Cohen, H., Zohar, J., Gidron, Y., Matar, M. A., Belkind, D., Loewenthal, U., Kozlovsky, N. and Kaplan, Z. (2006) Blunted HPA axis response to stress influences susceptibility to posttraumatic stress response in rats. Biol. Psychiatry 59, 1208-1218.

57. Gomez-Lazaro, E., Garmendia, L., Beitia, G., Perez-Tejada, J., Azpiroz, A., and Arregi, A. (2012) Effects of a putative antidepressant with a rapid onset of action in defeated mice with different coping strategies. Prog. Neuropsychopharmacol. Biol. Psychiatry 38, 317-327.

58. Castro, M. E., Diaz, A., del Olmo, E., and Pazos, A. (2003) Chronic fluoxetine induces opposite changes in $\mathrm{G}$ protein coupling at pre and postsynaptic $5-\mathrm{HT} 1 \mathrm{~A}$ receptors in rat brain. Neuropharmacology 44, 93-101.

59. Amigó, J., Díaz, A., Pilar-Cuéllar, F., Vidal, R., Martín, A., Compan, V., Pazos, A., and Castro, E. (2016) The absence of 5-HT4 receptors modulates depression- and anxiety-like responses and influences the response of fluoxetine in olfactory bulbectomised mice: adaptive changes in hippocampal neuroplasticity markers and 5-HT1A autoreceptor. Neuropharmacology 111, 47-58.

60. Linge, R., Pazos, A., and Díaz, A. (2013) Social isolation differentially affects anxiety and depressive-like responses of bulbectomized mice. Behav. Brain Res. 245, 1-6.

61. Paxinos, G., and Franklin, K. B. J. (2001) The Mouse Brain in Stereotaxic Coordinates. 350 pp. Academic Press, San Diego, California, USA. 
1 62. Edelstein, A. D., Tsuchida, M. A., Amodaj, N., Pinkard, H., Vale, R. D., and 2 Stuurman, N. (2014) Advanced methods of microscope control using $\square$ Manager 3 software. J. Biol. Methods 1, e10.

4 63. Livak, K. J., and Schmittgen, T. D. (2001) Analysis of relative gene expression 5 data using real-time quantitative PCR and the 2(-Delta Delta $C(T)$ ) Method. $6 \quad$ Methods 25, 402-408.

7 64. Taylor, S., Wakem, M., Dijkman, G., Alsarraj, M., and Nguyen, M. (2010) A 8 practical approach to RT-qPCR-Publishing data that conform to the MIQE 9 guidelines. Methods 50, S1-5.

10 65. Martínez-Cué, C., Martínez, P., Rueda, N., Vidal, R., García, S., Vidal, V., 11 Corrales, A., Montero, J. A., Pazos, A., Flórez, J., Gasser, R., Thomas, A. W., 12 Honer, M., Knoflach, F., Trejo, J. L., Wettstein, J. G., and Hernández, M. C. (2013) 13 Reducing GABAA a5 receptor-mediated inhibition rescues functional and 14 neuromorphological deficits in a mouse model of Down syndrome. J. Neurosci. 33, 15 3953-3966. 


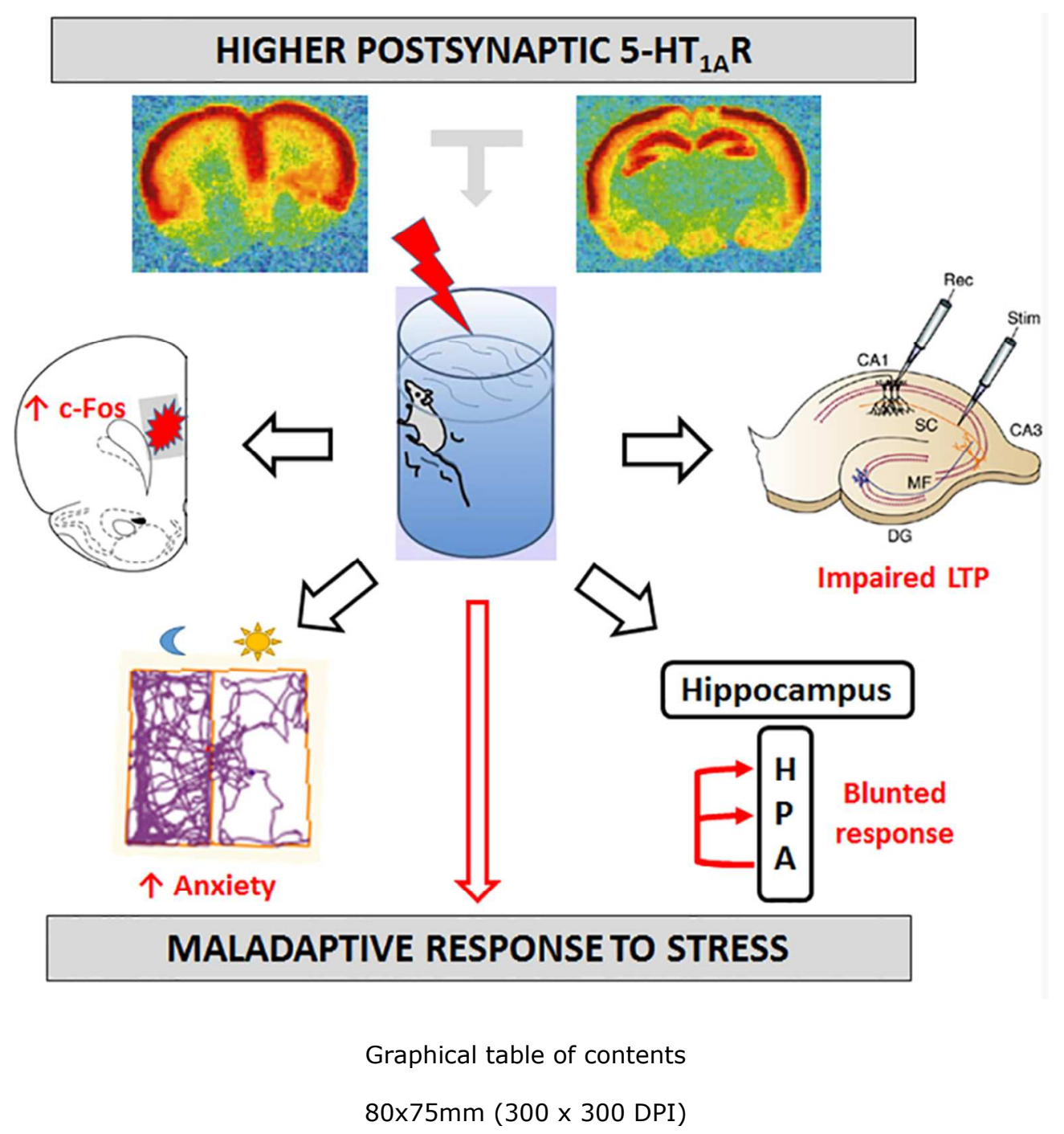




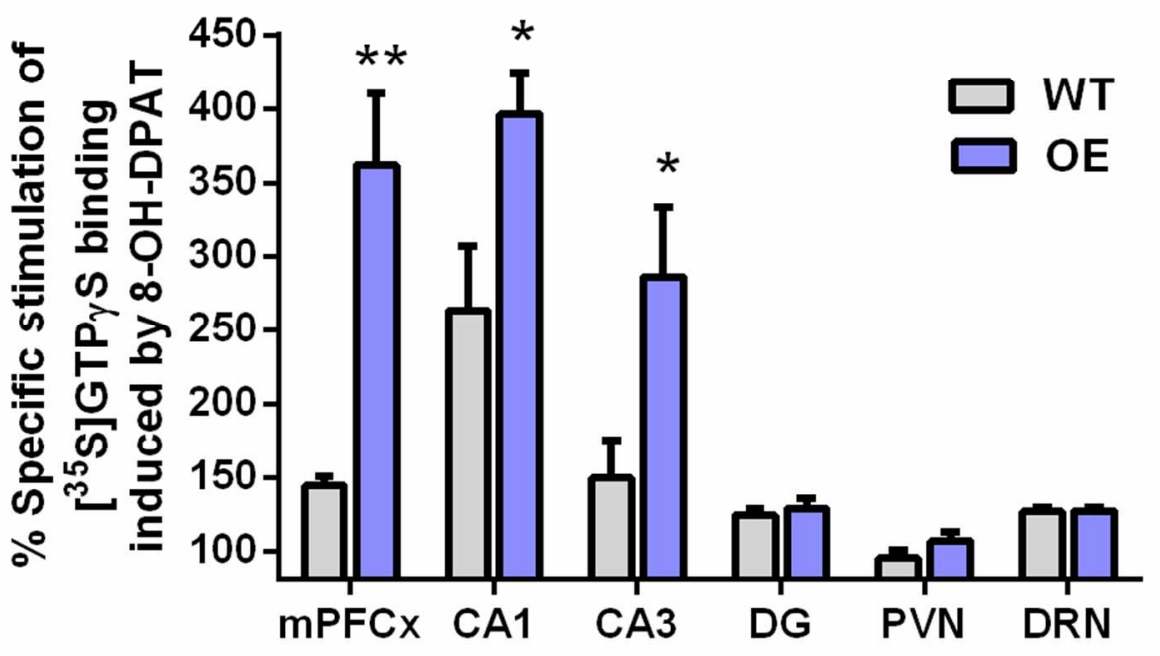

Figure 1

$85 \times 48 \mathrm{~mm}(300 \times 300$ DPI $)$ 
1

2

3

4

5

6

7

8

9

10

11

12

13

14

15

16

17

18

19

20

21

22

23

24

25

26

27

28

29

30

31

32

33

34

35

36

37

38

39

40

41

42

43

44

45

46

47

48

49

50

51

52

53

54

55

56

57

58

59

60
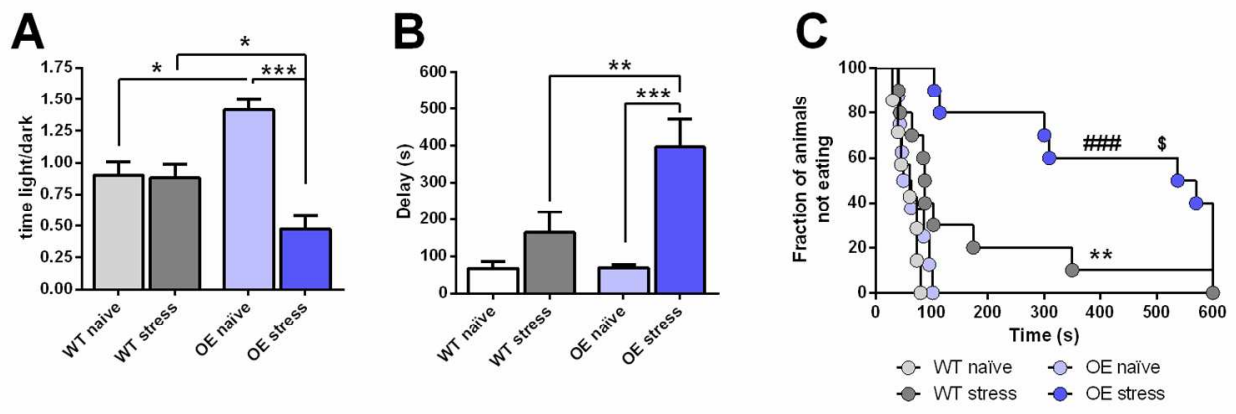

Figure 2

$140 \times 49 \mathrm{~mm}(300 \times 300 \mathrm{DPI})$ 

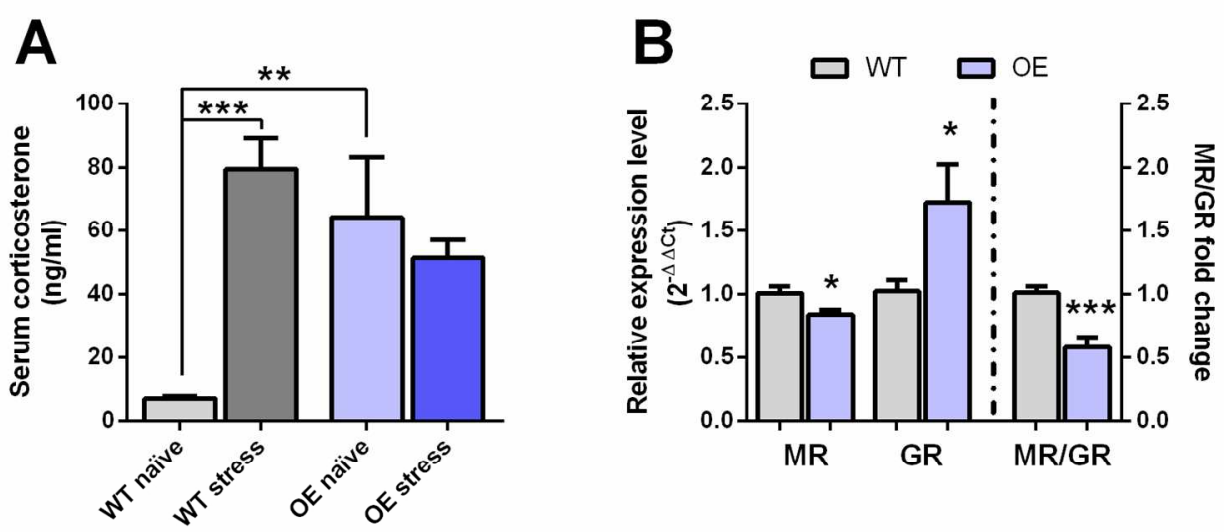

Figure 3

$140 \times 64 \mathrm{~mm}(300 \times 300 \mathrm{DPI})$ 

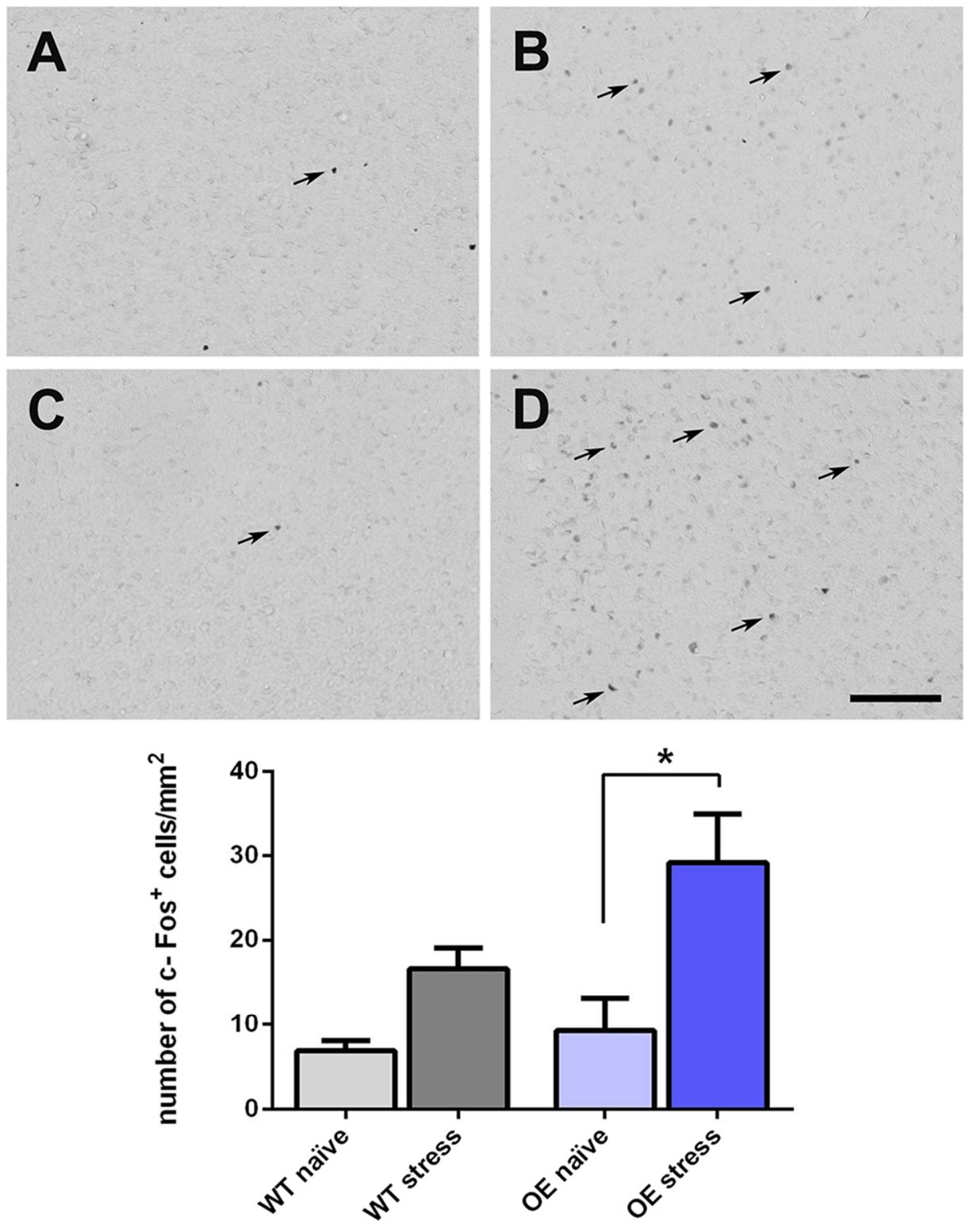

Figure 4

$85 \times 107 \mathrm{~mm}(300 \times 300$ DPI $)$ 

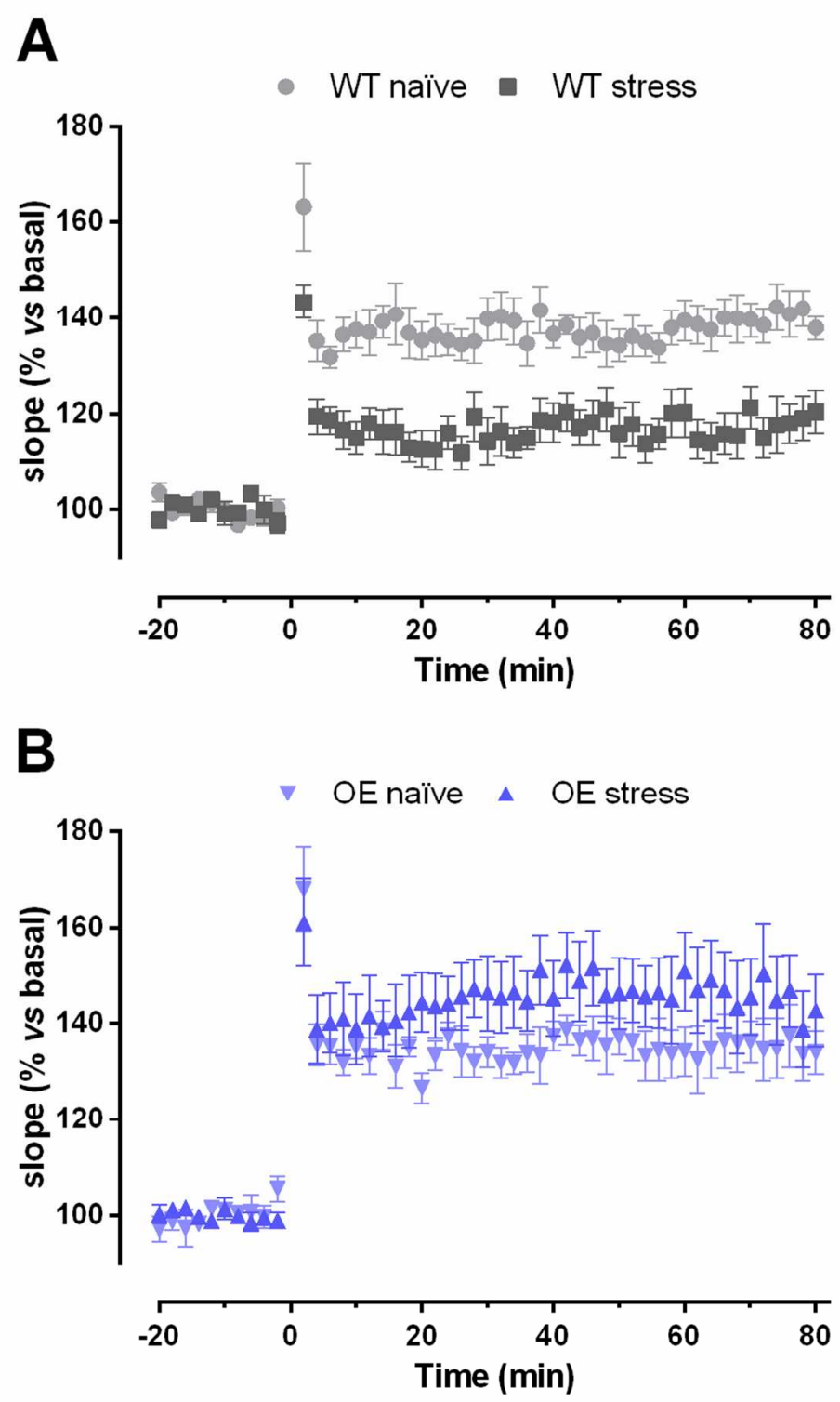

Figure 5 $85 \times 127 \mathrm{~mm}(300 \times 300 \mathrm{DPI})$ 
Figure 6 $346 \times 230 \mathrm{~mm}$ (96 x 96 DPI) 